\title{
IMAGE OF JAPANESE FAMILY IN ADVERTISING -PV/VANAH/WATER Ltd.-
}

\author{
I.G Surya ${ }^{1}$, K.A.D Apriliani ${ }^{2}$ \\ ${ }^{12}$ Jurusan Bahasa Asing, Universitas Pendidikan Ganesha, Singaraja \\ e-mail: gede.surya@undiksha.ac.id, avu.dina.apriliani@undiksha.ac.id
}

\begin{abstract}
Abstrak
Pada PV/vanah/ water menyisipkan bagaimana imaji keluarga di Jepang saat ini. Analisis ini bertujuan untuk memaparkan imaji keluarga di Jepang pada PV/ vanaH/ water. Pada PV/ vanaH/ water ini menampilkan air yang memiliki makna bahwa air ini merupakan air yang memiliki kandungan mineral . Mineral merupakan hal terbaik bagi tubuh. Sehingga memberikan yang terbaik bagi keluarga adalah kewajiban setiap anggota keluarga terutama anak laki-laki. Air ini diambil langsung diambill dari Gunung Fuji.Penelitian ini menggunakan metode penelitian kualitatif dan analisis semiotika Roland Barthes, yaitu sistem denotasi dan konotasi yang dapat digunakan dalam mencari lalu mengenali dan memahami tanda-tanda serta makna yang ditampilkan pada PV/ vanaH/ water. Penelitian ini berfokus pada imaji keluarga di Jepang pada PV/ vanaH/ water. Dengan meneliti PV ini diharapkan nantinya akan mendapatkan penjelasan mengenai imaji keluarga di Jepang.
\end{abstract}

Kata kunci: imaji, keluarga ,iklan, PV/vanaH/water, Jepang.

\begin{abstract}
In PV / vanah / water has a family image in Japan at this time. This analysis aims to describe the family image in Japan on PV / vanaH / water. In PV / vanaH / water it displays water that has mineral content. Minerals are the best thing for the body. So giving the best for the family is the duty of every family member, especially boys. This water is taken directly from Mount Fuji. This research uses qualitative research methods and Roland Barthes's semiotic analysis, a denotation and connotation system that can be used in finding and recognizing and understanding the signs and meanings displayed on PV / vanaH / water. This study focuses on family images in Japan on PV / vanaH / water. $B y$ researching this $P V$ it is hoped that later it will get an explanation of the family image in Japan.
\end{abstract}

Keywords : image, family, ad, PV/vanaH/water, Japan.

\section{Introduction}

In the era of intense competition, the marketing world is pushing every company to make advertising effectively and creatively. Advertising in the form of PV (Promotion Video) is one of the creations that exist. Not only want to promote the product, advertisers sometimes want to educate something good. Advertising is a special form of communication to fulfill the marketing function of a product (Jefkins, 2000: 20). The words and images used in advertisements are also called advertising communications, which have long been used by many companies. The combination of words and images on the product is a very effective communication to convey messages to consumers.

"The selection of the right words (verbal elements) with a compelling combination of pictures (nonverbal elements) will be able to evoke the meaning that a product wants to convey to its audience effectively" (Bungin, 2007: 225). On PV (promotion video) in 2015, the work of Kenji Kawasaki illustrated how water from Mt. Fuji is pure and has mineral content. Seen in this product tagline is "VanaH water mineral water", this shows that this product has the mineral content the body needs. This research focuses on the Vanah water PV tagline and family images in Japan which are illustrated by the process of extracting water. This advertisement was chosen to be researched because of its attractive promotion method and used the concept of family in Japan to attract consumers.

Based on the description before, the problem can be concluded as follows: "How is the image of a family in Japan in PV / vanaH / water?".

This paper will describe how families in Japan are in PV / vanah / water. Furthermore, it will be explained how important it is to provide the best for the family. To realize that, water is chosen as the best for the family. 


\section{Semiotic}

Semiotics comes from a Greek word, 'semeion' which means "sign" or seme which means "interpreter of signs". Semiotics is rooted in classical and scholastic studies of the art of logic, rhetoric, and poetics. "Sign" at that time was still meaningful in one thing that showed the existence of other things. When applied to language, letters, words, sentences have no meaning to themselves. Signs only carry meaning (significant) in relation to the reader. The reader is what connects the sign with what is signified (signifie) in accordance with the conventions in the language system concerned (Sobur, 2004: 17). Semiotics is the science of signs. The study of signs and everything related to them, how they function, their relationship with other signs, their transmission, and reception by those who use them.

According to Preminger (cited in Kriyantono, 2006: 261), this science considers that social phenomena or society and culture are signs. Semiotics studies the systems, rules, conventions that allow these signs to have meaning. The semiotic analysis seeks to find signs including things hidden behind a sign (text, advertisement, news) because the sign system is very contextual and depends on the user of the sign. The thinking of the user of the sign is the result of the influence of various social constructions in which the user of the sign is located.

Then, semiotics is a science or method of analysis to study signs. The basis of semiotics is the concept of signs, not only language and communication systems are composed of signs, but the world itself is also related to the human mind that consists entirely of signs because, if not so, humans would not be able to establish a relationship with reality. The language itself is the most fundamental sign system for humans, while nonverbal signs such as gestures, forms of clothing, and various other conventional social practices, can be seen as a kind of language composed of meaningful signs that are communicated based on relations (Sobur, 2004: 13).

Visual communication as a semiotic area

Visual communication semiotics aims to examine verbal signs (titles, subtitles, and texts) and visual signs (illustrations, logos, typography, and visual order) visual communication design with the semiotic theory approach. With visual semiotic analysis, the meaning contained behind the verbal signs and visual signs of visual communication design works will be obtained. With the semiotic theory approach, visual communication design work will be able to be classified based on the signs, codes, and meanings contained therein (Tinarbuko, 2008: 9). Although the main object of visual communication is visual communication elements, namely lines, areas, spaces, colors, shapes, and textures, but its development, visual communication design also involves non-visual elements, such as writing, sound or verbal language.

Visual communication design is the study of communication concepts and expressions of creative power, which is applied in visual communication media by processing graphic design elements consisting of images (illustrations), letters and typography, colors, composition, and layout. All of that is done to convey messages visually, audio, or audiovisual to the target audience. The universe of visual communication design is always dynamic, full of movement, and change because of modern civilization and science.

In analyzing a sign, it will be greatly helped by the theory of visual semiotics. This is interrelated between visual communication theory and Roland Barthes's theory of semiotics. In the theory of Barthes, it is revealed that there are several concepts such as signification, denotation, connotation, and metalanguage or myth. To find some of these concepts in a media in this context PV Vanah water. With the point of view in terms of shape, color, angle, space, and texture it will make it easier to find the connotation or denotation of a sign.

\section{Barthes Theory}

The theory used in this paper is Roland Barthes's Semiotics Theory. Roland Barthes is an expert who subsequently continues and develops theories owned by Saussure. According 
to Barthes, semiotics has several concepts, namely signification, denotation, connotation, and metalanguage or myth.

Signification is a process in the form of action, which binds a marker and a marker and produces a sign. Denotation is the first stage of signification which is the relationship between signifier and signified is a sign to external reality. The connotation is the second stage of significance (Sobur, 2009: 15).

Metalanguage or myth serves to reveal the truth for dominant values that apply in a certain period. In addition, Barthes also sees another aspect of labeling, the myth that marks a society. Myth, according to Barthes, lies at the second level of signification, so after the sign-signifier-signified system is formed, the sign will become a new marker which then has a second sign and forms a new sign. So, when a sign that has a connotation meaning then develops into a denotation meaning, then the meaning of the denotation will become a myth.

In the Vanah Water ad, this is a product promotion that inserts how families are in Japan. This can be realized very well by Kenji Kawasaki in the Vanah water PV. It is very visible how the effort to provide the best water to the family. By seeing the concept of 'le' can still be seen at this time. That can be seen and displayed on the PV, how close family relations are shown. At the time the grandmother was sick, the other family was still treating and visiting her in the hospital.

It is further seen in PV, a grandchild who gives something that is best so that it can be enjoyed by people who are important to him namely grandmothers. The best thing is pure water taken directly on Mount Fuji.

\section{'le' Concept and Japanese family}

lenaga (1978, cited in Anwar 2010) argues that the concept of 'le' must be understood from its distinctive features that distinguish it from the concept of family in Western society, namely: (a) there must be someone who becomes a kachou (head of the family) as the ancestral representative to lead the extended family of 'le' concerned; (b) there must be obedience to respect kachou and (c) the continuity of family history from the past to the present.

The 'le' system then continued for several generations so that the 'le' system in a family become to three concepts such as the Kanmei concept, the emergence of the family name; the concept of Kakaku which gave rise to family status and the concept of Kafu which preserved family habits.

\section{Kaku Kazoku}

Matsubara (1983, cited in Anwar 2010) even argues that Kaku kazoku is a family system that is increasingly popular in Japanese society, as a substitute for the le system. According to him, there are three main factors that caused the le system to be displaced by the Kaku kazoku system, namely: (1) The loss of the legal foundation in 1946, as well as a change in Civil Law on Family and Inheritance in 1948; (2) The growth of thinking about democracy in various walks of life after World War II through a modern educational system that is evenly distributed throughout Japan, forming public opinion that considers the le system less democratic, and (3) There is a drastic change in the pattern of family life in Japan after in 1955 and above.

\section{Method}

This type of research is a qualitative semiotic analysis used refers to the Roland Barthes Theory of two-stage significance (denotation and connotation). In this paper, data obtained using the techniques of listening and note-taking. First listened to the PV / vanah / water advertisement and then noted the sign displayed. So that the sign can be interpreted.

\section{Discussion}

At this step, it will be explained how the PV represents the best products and families in Japan. By taking a few screenshots which will then be analyzed using Barthes's semiotics. The focus of the analysis starts from the level of denotation-connotation to the search for a 
myth. After conducting research found two family images on PV / vanah / water. Both of these images are the embodiment of the le concept in Japan, but not as thick as before. These two things are:

1. Kafu,

2. Chounan obligations.

The PV / vanah / water tells of a child eating with his parents watching a very pure drinking water advertisement taken directly from Mount Fuji. Then he remembered his grandmother who was sick and was in the hospital. Then the next day he made a memo that said he went to get the pure water. Then he immediately headed for Mount Fuji using a bicycle with a distance from his home that is very far and through a steep road. Although he had fallen down, he finally arrived and took the pure water and put it in the water storage. On the way home, he got rained on and when he arrived at the hospital he met his parents. When the water is poured into a glass and drunk by his grandmother. His grandmother also smiled happily with gratitude. This PV ended up being shown a happy and harmonious family after his grandmother drank water.

In the discussion, the section will be divided into two sections according to the distribution of results obtained.

\section{Kafu}

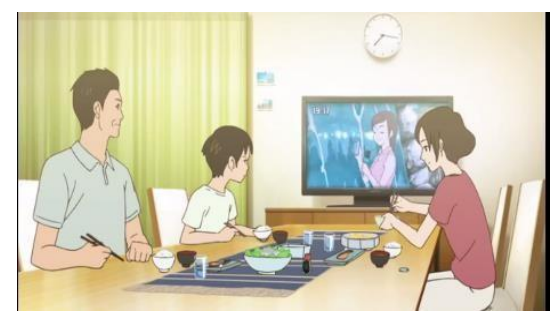

Figure 1. Eating with Family

Figure 1. is the opening scene for PV / Vannah / water. there are 3 elements namely: visuals in the form of depictions of families in Japan who are eating together, audio water from advertisements on TV, and clear blue water. Then it can be explained namely.

\begin{tabular}{|l|l|l|}
\hline Signifier & $\begin{array}{l}\text { Signified: } \\
\text { A small family in Japan } \\
\text { eating together }\end{array}$ \\
\hline $\begin{array}{l}\text { Signifier: } \\
\text { Daily activities of a family in Japan }\end{array}$ & $\begin{array}{l}\text { Signified: } \\
\text { The image or view of society about the } \\
\text { family in Japan }\end{array}$ \\
\hline $\begin{array}{l}\text { Myth: } \\
\text { Views of families in Japan today }\end{array}$ & \\
\hline
\end{tabular}

Figure 2. Analysis Mapping of Figure 1

From the scene that depicts families in Japan when eating together with their families, the meaning of denotation from Figure 1 is the daily conditions of a family in Japan who always eat together when at home. Furthermore, the scene can be interpreted as a 
connotation, such as the current condition of the family in Japan, which consists of father, mother, and child.

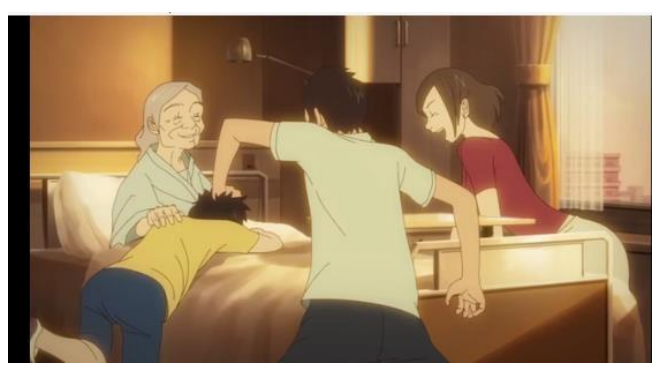

Figure 3. Taking Care of a Family

Figure 3 is one of the scenes in PV / Vanah / water. there are 3 elements namely: visuals in the form of a depiction of a family in Japan and grandmother who drinks water, audio of the water that grandma drinks, a happy smile of a family. Then it can be explained namely.

\begin{tabular}{|l|l}
\hline & Signified: \\
Signifier & \\
grandmother who was in the & \\
hospital
\end{tabular}

Signifier :

Activities to visit families in the hospital

\section{Signified:}

Caring for each other in the family members while still providing the best for the family

Myth:

Maintaining the le concept in several families in Japan, where Kachou and Chounan still do their best

Figure 4. Analysis Mapping of Figure 3

Based on Figure 3 that appears at the end of the PV which illustrates how harmonious the family is. Then it can be interpreted as denotation, namely the activity of visiting a sick family in the hospital. Furthermore, the scene can also be interpreted as a connotation, namely the preservation of the le concept in families in Japan.

From Figures 1, it can be understood that this is in line with one of the concepts that developed in families in Japan namely Kaku Kazoku. However, in its application, it emphasizes more on one of the concepts of le namely Kafu. Kafu is an obligation to keep doing family habits beforehand. This habit for example like eating together when at home.

Furthermore, in Figure 3 we can understand that Kafu is one of the remnants of the le concept which is the basis of kinship in traditional Japanese families. Since the enactment of the Showa law based on democratic principles, the legal system of this le no longer exists in the life of modern Japanese families. However, even so, there are some habits left by the le system that is still practiced by Japanese society. In addition to the three concepts mentioned above, the traditional ceremonial worship of ancestors is still carried out as a means to interact both with fellow community members in the vicinity and with family 
members who live far apart. In addition, in some urban communities, there are still nuclear families who live close to their parents. A lifestyle like this in addition to being a family picture that maintains the concept of traditional family le also has another function that is more relevant to the needs of family members who live in urban areas. In some families close to a place to live with parents give their parents comfort because they do not have to be lonely in his old age or do not need to live in a nursing home. For some families whose husband and wife work or are known as Tombataraki, the presence of the two people in a nearby place makes them more calm leaving the children at home because they are under the supervision of the family.

Then, it can be learned that, when progress is very modern times with the principle of freedom. We must still care for our parents. This can still be done in a way, keeping abreast of the times with all modernity, but not forgetting traditional traditions and still carrying them out. Although it is no longer the same because it is adapted to the times.

\section{Chounan Obligations}

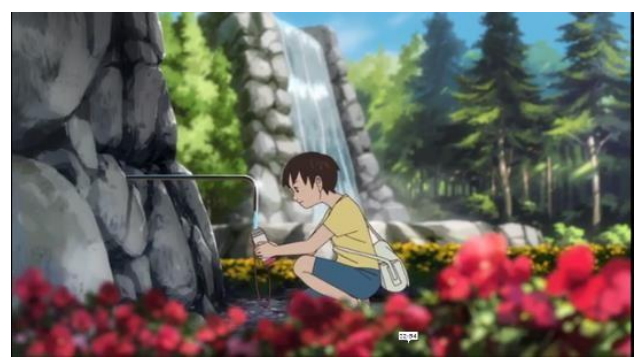

Figure 5. Take Water

Figure 5 is one of the scenes in PV / Vanah / water. there are 3 elements such as visuals in the form of depictions of boys who take water, audio water from water sources, and the natural environment. Then it can be explained namely.

\begin{tabular}{|l|l|}
\hline Signifier & \\
\hline $\begin{array}{l}\text { Signifier: } \\
\text { Efforts to provide water with pure mineral content } \\
\text { directly from the source }\end{array}$ & $\begin{array}{l}\text { Signified: } \\
\text { The obligation of a Chounan to continue } \\
\text { the obligation of the father who } \\
\text { continues to provide the best for the } \\
\text { family }\end{array}$ \\
\hline $\begin{array}{l}\text { Myth: } \\
\text { Chounan's image in carrying out the obligation to continue giving the best for the family }\end{array}$ \\
\hline
\end{tabular}

Figure 6. Analysis Mapping Figure 5

Based on the scene in Figure 5, the process of taking water starts from the house, Mt. Fuji, and in the hospital. The meaning of the denotation of the scene is the activity of a child fetching water for the grandmother at a spring. While the meaning of the connotation is how a Chounan in a Japanese family to carry out the obligation to provide the best for the family.

Furthermore, this is in accordance with the explanation from Nakane (cited in Lawanda, 2009 ; 16) In the le system, the father is Kachou the "head of the family" who holds power and Chounan "the first son" is the main heir and successor to le. As two people who have 
high positions in le, both Kachou who is the head of le, and Chounan who is a Kachou candidate get special treatment from other le members.

Then, in PV it can be seen that the Chounan or firstborn male child continued to carry out traditions and customs that had lasted long ago. That is still giving the best for the family and caring for their families with all their hearts.

What can be learned from PV / vanah / water is about the importance of caring for parents as a form of respecting and repaying all the affection given to us until our parents die later.

From the two discussions it can be concluded that an argument such as, in PV / vanah / water, there are two concepts of le that still persist. Then, the change in the concept of le described is a social phenomenon.

These two concepts are Kafu and Chounan's obligation. As expressed by lenaga (1978 cited in Anwar, 2010) regarding the concept of le which is divided into three. But in PV there is only one concept, Kafu. Nakane (cited in Lawanda, 2009: 16) revealed that Chounan had an obligation to continue the work of his father or Kachou.

So based on the results and discussion, a myth is obtained from PV / vanah / water that families in Japan are happy.

\section{Conclusion}

From some images about family in Japan, through PV / vanah / water it can be concluded that although there are modern family principles that emphasize freedom from family members, there are still families who use the principle le, but not as thick as the tradition that existed in the past.

The PV maker is able to promote the product well and educate consumers not to forget the concept of le to the family. Some of these principles are among others such as Kafu, and Chounan Obligations.

\section{Reference}

Anwar, E., N. 2010. Ideologi Keluarga Tradisional " IE " dan Kazoku Kokka pada Masyarakat Jepang Sebelum dan Sesudah Perang Dunia II, V, 194-205 ( access date 20 Mei 2018 from http://wacana.ui.ac.id/index.php/wjhi/article/viewFile/212/202 )

Bungin, B. 2007. Penelitian Kualitatif: Komunikasi, Ekonomi, Kebijakan Publik, dan IImu Sosial Lainnya. Jakarta: Putra Grafika

Kriyantono, R. 2006. Teknik Parktis Riset Komunikasi. Jakarta: Kencana Perdana

Lawanda, I., I. 2009. Matsuri dan Kebudayaan Korporasi Jepang. Jakarta: ILUNI Kajian Wilayah Jepang Press

Sobur, A. 2004. Semiotika Komunikasi. Bandung: Remaja Rosdakarya 2009. Analisis Teks Media. Bandung: Remaja Rosdakarya

Tinaburko. S. 2008. Semiotika Komunikasi Visual. Yogyakarta: Jalasutra 